\title{
Presentación del monográfico Los abrazos rotos
}

Como viene siendo habitual en el último Almodóvar, cineasta del que siempre se espera que contribuya a levantar el ánimo del cine español, Los abrazos rotos resultó un filme controvertido en su estreno, sobre todo para la crítica. Así, la mezcla de referencias cinematográficas de las que se nutre la película, sin duda uno de sus aspectos más relevantes, sirvió a determinados sectores de la crítica para arremeter contra la figura del autor, al ver en ello "un pretencioso autohomenaje, un plagio de sí mismo" (Época), o "una descarada y vacía forma de autopromoción" (Gara), mientras que otros sectores más reducidos destacaban, por el contrario, cómo esas referencias servían al filme para "evidenciar su calidad estética" (La Razón). Se vertían de este modo opiniones que, limitándose únicamente a expresar puntos de vista sin otro apoyo que el gusto del crítico, para nada entraban en la materialidad de un filme que, por su riqueza plástica y teórica, se constituye en una de las cimas de la obra almodovariana.

Se hace por ello necesario volver sobre este filme ahora, cuando ya el tiempo pasado ha contribuido a decantarlo, y aprovechando el espacio que nos brinda la revista Fotocinema, que ofrece sus páginas a los investigadores interesados en reflexionar sobre el cine y la fotografía. Como la crítica señalaba, Los abrazos rotos se nutre de imágenes procedentes de otras obras, entre ellas las del propio Almodóvar; imágenes cuya conjugación resulta del máximo interés teórico por cuanto enriquece de manera notable la teoría de la transtextualidad, a cuyo repertorio de términos añade otros nuevos como la "síntesis intratextual" (reunión de imágenes tomadas de este mismo filme) o la "autocita modificada" (reelaboración de imágenes tomadas de otros filmes almodovarianos), noción ésta sobre la que, por lo demás, se edifica La concejala antropófaga, película que aún estando separada de Los abrazos rotos, es parte estructural de ella. Pero también es importante en Los abrazos rotos su despliegue y declinación de una amplia gama de narradores, desde el personaje-narrador a la voz en over, 
cuyos relatos parciales van construyendo sucesivamente un tejido narrativo a modo de puzzle. Tejido sobre el que a su vez despuntan, en un interesante feedback, imágenes cuyos ecos, reenvíos y complicidades generan auténticos programas iconográficos.

Sobre estas y otras temáticas, abordadas, como podrá constatarse, desde metodologías muy diversas, versan los artículos que componen este dossier, que incluye también sendos trabajos que reflexionan sobre la recepción crítica del filme a ambos lados de los Pirineos y sobre el fracaso comercial de la película.

Pedro Poyato 